\title{
Feminist and Queer Practices in the Online and Offline Activism of Occupy Wall Street
}

\author{
EVE NG, Ohio University \\ SOPHIE TOUPIN, McGill University
}

\begin{abstract}
While the Occupy movement has attracted popular and academic interest since 2011, there has been relatively little attention to the significance of feminist and queer practices and discourses to the movement. Drawing from feminist theory, social movement studies, and digital media studies, this paper presents empirical research conducted at Occupy Wall Street (OWS) that highlights feminist, queer, and trans contributions to OWS from its inception, with a focus on the Trans World Order Affinity Group (TOAG). Through its activities at Zuccotti Park as well at its website and on social media, TOAG has challenged gender norms, heteronormativity, and transphobia in both the physical and virtual domains of OWS, and been a key contributor to its online prominence. As such, the group offers an illuminating case study of the challenges and successes of realizing feminist and queer agency during key developments of a major social movement. More generally, this project provides an important corrective to the prominence of class in how Occupy has been discussed and conducted, pointing out how other axes of inequality have also stratified Occupy itself. In addition, it addresses central issues about new media and participation, including negotiating differences between diverse activist groups, the efficacy of digital activism, and the relationship between online and offline strategies.
\end{abstract}

\section{KEYWORDS}

Feminism, media activism, Occupy Wall Street, social media, social movements, queer.

\section{Introduction}

Since the emergence of the Occupy movement on September 17, 2011, the 'We are the 99\%' slogan has resonated widely. In a context of severe economic crisis, appealing to class disparity as its main public narrative succeeded in rallying a wide array of people behind the movement. By lowering the barriers of identification to a broad and simple signifier, the slogan at face value fostered an ethos of co-existence, diversity and inclusiveness. However, the focus on the economic, both in the public domain and within Occupy's own discourses, was often narrow, overshadowing the intersections of class with other axes of inequality such as gender, sexual orientation, citizenship and race. Nevertheless, these inequalities and the groups that have sought to foreground them constituted the movement in significant ways, both in the virtual and physical world. This paper examines the extent to which feminist and queer discourses and 
practices have richly shaped, and been shaped by, the Occupy movement. While there has been a recent flurry of academic analyses about Occupy, few have looked at the feminist contributions within Occupy, whether online (but see Boler 2012; McMillan 2011) or offline (see Alcoff 2012; Arruzza 2012; Conroy 2012; Talcott and Collins 2012). We draw on digital media studies, social movement studies, and feminist theory to present an intersectional feminist analysis that puts feminist critique into dialogue with the movement's discursive repertoire, recognizing both the challenges and possibilities for realizing feminist agency at a moment when the validity and methods of digital activism are still being contested.

Our study is based on field research (which we describe in more detail below) of Occupy Wall Street (OWS), particularly its various feminist activist groups and caucuses. Their often independent but nonetheless interrelated contributions are significant for several reasons. First, debates and dialogues arising from the actions of these groups, though sometimes tense, constructed a more complex movement imagination that helped broaden Occupy from its original economic inequality frame. The identification of discrimination, oppression, and privilege within both the structures of the encampments and the larger economic crisis also highlighted the necessity of feminist and queer approaches for social movements more generally. In addition, Occupy's decentralised, horizontal and networked character enabled traditionally marginalised groups to shape the movement's directions and discourses and enrich its multinodal, multi-layered dimensions, with the cyber and technofeminist practices at OWS suggesting future directions for effective online and offline feminist activism.

\section{Moving beyond individualist discourses: the unity in diversity frame}

Feminists, like other activists, are situated in particular social and historical contexts. Dominant trends that have influenced much mainstream U.S. feminist activism in the past years, including a focus on individual agency and the 'particular,' cannot be separated from late capitalism and the rise in advanced technologies (Arruzza 2012). Hence, the politics of personalisation and individuation have created new forms of affect (Ahmed 2004, 2010; Larsen 2004), producing mobilised individuals in part through social media and digital technologies (for example, mobile phones, Facebook, Twitter) that appeal to personalised choices (Bennett 2012; Bennett and Segerberg 2011).

Individualism is in some tension with the principle of unity that has been widely discussed in social movement theories. For example, Charles Tilly (2004) identifies unity as one key factor in determining the effectiveness of social movements (with three other elements being worthiness, numbers, and commitment); and, referring to Donatella della Porta's (2005) analysis of world and regional social forums, Anastasia Kavada argues that unity in action is still possible amongst groups with strong ideological differences, exemplified by how the 2000 global justice movement was able to practise 'unity in diversity' $(2010,43)$. In the case of Occupy, the unity in diversity frame was epitomized from the start by the slogan 'We are the $99 \%$,' which sought to unite a range of people along a binary division of class, where the 1 per cent owned and controlled wealth, while the other 99 per cent were subject to the actions of those in power. 
As scholars have discussed, the fierce implementation of a neoliberal paradigm has accelerated the rarefication of putatively public spaces, or what Michael Hardt and Antonio Negri (2009) call 'common' spaces (for example, see Brenner and Theodore 2002; Peterson 2006). Coupled with the effects of 'casino capitalism' (Strange 1997) and its corollaries (for example, foreclosures and mounting debt amongst ordinary workers alongside bank bailouts and the alignment of elected officials with business interests), this has worked against opportunities for people to encounter radical alternatives and organise in their communities, workplaces and schools. The Occupy movement, with its acts of reclaiming public space, explicitly aimed at countering the discourses and effects of neoliberal logic.

However, recent scholarship has contested the extent to which the unity in diversity frame and aspirations for more participatory forms of democracy have been realized in Occupy mobilizations. For example, Emahunn Raheem Ali Campbell (2011) has noted that the language of 'occupation,' particularly as deployed by a predominantly white body of occupiers in the U.S., has been largely ignorant of the meanings and realities of occupation for indigenous communities. Campbell, along with Jeffrey S. Juris et al. (2012), highlights the insufficient recognition of racial hierarchies amongst Occupy encampments, particularly early on. Furthermore, there have been long-time cautions against what Freeman (1972) termed the 'tyranny of structurelessness' that typifies many social movements, where lack of formal structures ends up favoring those who already enjoy gender, class, and race privilege, and facilitates the informal power of certain individuals or cliques. Even amongst feminist groups, the formation of 'tight-knit communities based on friendship and trust [...] fostered unity and commitment, but hindered the integration of new members and thwarted leadership initiatives' (Smith and Glidden 2012, 289).

Thus, Campbell (2011) argues that Occupy was not a place of simple unity in the sense that common goals or demands were inevitably shared, but rather a place of togetherness where emotional and physical connections were experienced. Although such togetherness, new for many individuals, opened up various collective possibilities, there were nonetheless constant tensions in the spaces of Occupy around questions of unity and inclusion, which sometimes helped move issues forward, but also often resulted in failures to deal with them effectively.

\section{Cyberfeminism and collective agency online}

There have been ongoing debates about the impact of digital technologies on political engagement, including the extent to which they encourage meaningful and effective participation. Certainly, new media allows cultural agents to circumvent some of the constraints associated with traditional print, radio, television, and film, and enables various modes of interactivity often labeled 'participatory' (for example, see Jenkins 2006). The possibilities of digital technologies for those who are politically and symbolically under-represented have therefore made them central to the communicative practices of contemporary social movements. In an early assessment of new media and political participation, Richard Davis and Diana Owen (1998) identified the Internet as serving several functions, including providing online space for 
political discussion, and more recently, Manuel Castells (2008) has noted the importance of contemporary media to the structure and development of an international public sphere:

The contemporary global public sphere [...] is built around the media communication system and Internet networks, particularly in the social spaces of the Web 2.0, as exemplified by YouTube, MySpace, Facebook, and the growing blogosphere [...]. (ibid., 89-90)

However, user engagement with new media is not necessarily progressive in its character or outcomes, and does not always offer effective political agency. As Erika Polson discusses, new media practices also help produce elite social formations, including the new subjectivities of 'an emerging global middle class' $(2011,149)$. And while scholars such as Castells $(2008,2012)$ and Bernard Stiegler (2008) have discussed how agency through social media can connect individuals to wider movements of social change, Tiziana Terranova $(2000,2004)$ and Natalie Fenton and Veronica Barassi (2011) argue that social media use has entrapped individuals, diminished collective endeavours and voices, and put the individual under constant surveillance by the state, corporations, or other individuals. There has also been a recent backlash against 'slacktivism' (Gladwell 2010) or 'clicktivism' (White 2010) online, where it is argued that practices such as liking or sharing content via Facebook and Twitter or 'clicking on a few links' (White 2010) cannot replace the effectiveness of traditional methods of protest that involve physical presence. More generally, Nico Carpentier cautions that 'the participatory potential of media technologies remains dependent on the way that they are used [...] web 2.0 technologies can perfectly be used in top-down non-participatory ways' $(2007,112)$, and Graeme Turner (2009) argues similarly against the assumptions associated with 'digital optimism' and egalitarian goals.

In feminist scholarship, earlier utopian visions of the Internet (for example, Plant 1997) that imagined online spaces as free of offline discrimination and violence have been countered by more critical accounts both about how hierarchies of identity play out in online representations and discourses (Campbell 2004; Daniels 2009; Kendall 2002; Nakamura 2002, 2007) and about the gendered dimensions of digital access (Eubanks 2011; Sassen 2002). Even before the Internet, Cynthia Cockburn (1985) had argued against technology's potential for women's liberation, warning that male domination of technical skills and knowledge continued to maintain a gendered division of labour in the workplace. Seeking to move away from the dichotomy of both liberatory and dystopian discourses around technology, some feminist scholars have argued for developing theoretical and practical tools to counter the ways that the design and infrastructure of the web disadvantage certain demographic groups. In this way, what Sonia Núñez Puente and Antonio García Jiménez (2009; also see Puente 2011) called 'online feminist praxis' in their discussion of Spanish feminist portal sites would offer one avenue for 'a complex but productive political project in the midst of the highly contradictory digital landscape that offers women both peril and promise" $(2009,41)$, in line with what Judy Wajcman (2004) has also discussed as 'technofeminism'. 
As will be discussed in more detail below, feminist activism at OWS demonstrates both possibilities and problematic elements of new media, as well as the tensions that emerged from diverse groups participating in a movement that was never as unified as its slogan might suggest. Feminist collectives or affinity groups used social and new media to share information, organise and amplify their personal voices, but less common were instances where they foregrounded a collective voice and a collective agency through online media in ways that were explicitly intended to mirror their offline mode of actions. Following a summary of our methodology, we provide an overview of the feminist groups at OWS, discuss how these groups confronted offline and online hierarchies, particularly around gender and sexuality, and present a case study of one group, the Trans World Order Affinity Group (TOAG), to highlight their feminist and queer strategies.

\section{Methodology}

The data are drawn from an in-depth case study of OWS conducted from September to December 2012. Our research was limited to OWS - that is, Occupy's movement in New York City - to limit the boundaries and scope for the research, data collection, and analysis. Several qualitative methods were employed for conducting this research. First, virtual ethnography (Gajjala 2002) of websites and other digital communications tools (including Twitter, Facebook, Occupy Patriarchy, and OccupyWallSt.org) was undertaken to understand the virtual world created by and around OWS. Second, participant observation allowed one of the researchers to become familiar with the actors and groups involved and to obtain an overall view of feminist, trans and queer contributions, both online and off. Third, 17 in-depth semi-structured interviews lasting from one to two hours in length were conducted with feminists and their allies and then transcribed.

As feminist scholars, we are sensitive to questions of researcher positionality. There have been various critiques about how a researcher's racial, national, gender, sexuality, or class privilege relative to her subjects informs the negotiation of access, researcher-subject interactions, and the researcher's interpretation and write-up of data (for example, see Halpin 1989; Patai 1991; Smith 2004). Furthermore, although some feminists have argued that shared positionality between researcher and subject can be empowering to traditionally silenced voices (for example, see Behar and Gordon 1995), others have pointed out that the standard ethnographic strategy of building rapport with subjects along dimensions of perceived similarities can mask power differences to which critical researchers should be attentive (for example, Marcus 1998; Probyn 1993).

The fieldwork was conducted by one of the authors, Sophie Toupin, a scholar who has taken part in various social movements, including the Global Justice Movement, Occupy, and the 2012 Quebec Student Strike. In relation to the interviewees, Sophie was thus in part an insider, in particular as an Occupy participant and long-time activist, while being similarly or differently aligned with other occupiers along the dimensions of ethnicity and nationality (Québécoise), race (white), gender (female), sexuality (heterosexual), and class (middle class). She did not hide 
her activist and feminist commitments during her research, but nor did she presume that partial commonalities of identity would negate all dynamics of power and difference. We therefore recognize that the account we present here is situated by our particular positionalities, contributing a 'partial truth' (Clifford 1986) to a larger body of feminist and critical ethnographic work on Occupy.

\section{An Overview of Feminist Groups within OWS}

As OWS grew daily, more people joined the encampment and more working groups, committees, caucuses and affinity groups were formed. This was particularly notable for feminist groups. As a member of the Feminist Direct Action group (FemDA) commented:

I have never been involved in a 'group' or 'experience' that grew so fast. [...] There were feminists and queers here and people of colour, and they were talking about these issues and how they were all interconnected. (Member of the FemDA, interview, November 16, 2012)

The range of people who took part in OWS also brought different methods of struggles. Even though initially, direct actions (DA) seemed to dominate Occupy's main mode of actions, a FemDA member noted that these were often more popular amongst white middle-class men, while many women, people of colour, and queers 'pushed forward' a feminist and queer message through other powerful methods, such as consciousness raising, education through practice, and the formation of (self-identified) women/queer-only groups, both online and offline (member of the FemDA, interview, November 16, 2012).

The feminist groups of OWS exemplify both the diversity and the accompanying tensions within feminist activism as they negotiated a (new) common language and praxis. The space of togetherness created at OWS has not only been instrumental for feminists to (re)connect, but also to educate people who would not otherwise have learned about feminist, queer and trans practices, given the low mainstream profile and isolation that feminist struggles have experienced in the past decade. As a member of FemDA recounted, feminists and queers at OWS challenged participants to question dominant binaries and narratives of identity:

A friend organized a day on intersectionality [...] [which] people thought $[\ldots]$ was an academic term that did not really apply to what was going on. [...] I think that if it's explained well and if we slow down enough to talk about it, it makes a lot more sense than a single issue platform. (Member of the FemDA, interview, November 16, 2012) 
The following table, based on fieldwork at OWS, is a non-exhaustive summary of its feminist groups.

\section{Table 1: A non-exhaustive ethnography of the Feminist caucuses ${ }^{1} /$ groups within Occupy Wall Street}

\begin{tabular}{|c|c|c|c|}
\hline $\begin{array}{c}\text { Group's name \& website if } \\
\text { available }\end{array}$ & $\begin{array}{l}\text { Reasons for creating } \\
\text { the group }\end{array}$ & Composition & $\begin{array}{c}\text { Main tenets, achievements and } \\
\text { challenges }\end{array}$ \\
\hline $\begin{array}{l}\text { Code Pink } \\
\text { http://www.codepink4peace.org/ }\end{array}$ & $\begin{array}{l}\text { Existence pre-dated } \\
\text { OWS } \\
\text { One of the few } \\
\text { organisations at OWS } \\
\text { foregrounding anti- } \\
\text { militarism and peace }\end{array}$ & $\begin{array}{l}\text { Code Pink staff, } \\
\text { women, queers }\end{array}$ & $\begin{array}{l}\text { Entry point for families and for } \\
\text { older women } \\
\text { Organised media trainings for } \\
\text { women and queers } \\
\text { Organised many theatrical direct } \\
\text { actions (throwing pink bras at } \\
\text { banks, handing pink cupcakes to } \\
\text { the "rich") } \\
\text { Formed 'Women Occupy,' a } \\
\text { network of women and queers } \\
\text { who connected through Facebook } \\
\text { to share their experiences at } \\
\text { Occupy sites: } \\
\text { http://www.womenoccupy.org/ }\end{array}$ \\
\hline Divine Feminine & $\begin{array}{l}\text { Arose from the need } \\
\text { of 'women' to talk to } \\
\text { other 'women' in a } \\
\text { male-dominated } \\
\text { encampment }\end{array}$ & $\begin{array}{l}\text { Female-bodied or } \\
\text { female-identified } \\
\text { people, or anyone } \\
\text { who experienced } \\
\text { oppression as a } \\
\text { woman }\end{array}$ & $\begin{array}{l}\text { A safe discussion group } \\
\text { Quickly disappeared }\end{array}$ \\
\hline $\begin{array}{l}\text { FemDA (Feminist Direct Action) } \\
\text { a.k.a. Fem Block }\end{array}$ & $\begin{array}{l}\text { Aimed at gender } \\
\text { liberation through } \\
\text { mass direct action } \\
\text { against capitalism }\end{array}$ & $\begin{array}{l}\text { Any interested } \\
\text { feminists }\end{array}$ & $\begin{array}{l}\text { Grounded in anarcha-feminist } \\
\text { thoughts } \\
\text { Organised many direct actions (for } \\
\text { example, marches) and trainings } \\
\text { (for example, 'Know Your }\end{array}$ \\
\hline
\end{tabular}

\footnotetext{
${ }^{1}$ Caucuses are for people who share institutionalised marginalisation and oppression, and they attained special recognition first within the General Assemblies (GA) and then with the Spokes Council of OWS. In late October 2011, the General Assembly of Occupy Wall Street voted to adopt the Spokes Council as a new governance structure. The Spokes Council model can be understood as an assembly of assemblies, and was meant to improve coordination, accessibility and transparency at Occupy Wall Street, and to better empower marginalized groups such as the Women of Occupy Wall Street (WOW), the Queer Caucus and the People of Color Working Group to communicate their needs and be involved in decision-making.
} 


\begin{tabular}{|c|c|c|c|}
\hline & & & Rights') \\
\hline $\begin{array}{l}\text { FemGA (Feminist General } \\
\text { Assembly) }\end{array}$ & $\begin{array}{l}4 \text { FemGA groups } \\
\text { were organised from } \\
\text { June to September } \\
2012\end{array}$ & $\begin{array}{l}\text { Feminists and } \\
\text { their allies }\end{array}$ & $\begin{array}{l}\text { Brought together people that had } \\
\text { never participated in Occupy } \\
\text { Addressed some of the same } \\
\text { issues as WOW (see below) did, } \\
\text { but with more reticence } \\
\text { Did not connect queer theories } \\
\text { with feminist theories } \\
\text { Used gender binary and language } \\
\text { that treated 'girls,' 'sisterhood' } \\
\text { and 'women' as fixed categories }\end{array}$ \\
\hline People of Color Working Group & $\begin{array}{l}\text { Aimed at developing } \\
\text { critical consciousness } \\
\text { about oppressive } \\
\text { actions, behaviour } \\
\text { and identity within } \\
\text { OWS and extending } \\
\text { OWS's reach to those } \\
\text { most affected by the } \\
\text { current crisis }\end{array}$ & $\begin{array}{l}\text { People of colour } \\
\text { All genders }\end{array}$ & $\begin{array}{l}\text { Blocked the passing of the } \\
\text { Declaration of Occupy Wall Street } \\
\text { (triggered the need for a PoC } \\
\text { segment), amending a line stating } \\
\text { that oppression happened in the } \\
\text { past } \\
\text { People of colour who felt } \\
\text { apprehensive about Occupy used } \\
\text { PoC as an entry point } \\
\text { One of three caucuses recognised } \\
\text { by the OWS GA/Spoke council } \\
\text { http://www.nycga.net/groups/ }\end{array}$ \\
\hline $\begin{array}{l}\text { Queer/LGBTQIA2Z Caucus } \\
\text { https://queerows.wordpress.com/ }\end{array}$ & $\begin{array}{l}\text { Formed to increase } \\
\text { critical awareness } \\
\text { about LGBTIQA2Z } \\
\text { issues (the acronym } \\
\text { encompasses } \\
\text { "lesbian, gay, } \\
\text { bisexual, transgender, } \\
\text { intersex, questioning, } \\
\text { asexual, two-spirit, } \\
\text { zhe/zher," where } \\
\text { "zhe/zher" are } \\
\text { gender-neutral } \\
\text { pronouns) }\end{array}$ & $\begin{array}{l}\text { Anyone who } \\
\text { identified as } \\
\text { queer/ } \\
\text { LGBTQIA2Z }\end{array}$ & $\begin{array}{l}\text { Educated individuals and OWS } \\
\text { about LGBTIQA2Z culture and } \\
\text { concepts } \\
\text { Came up with a queer language } \\
\text { guide (Queer/LGBTQIA2Z } \\
\text { Caucus, 2011) } \\
\text { One of three caucuses recognised } \\
\text { by the OWS GA/Spoke council. } \\
\text { http://www.nycga.net/groups/ }\end{array}$ \\
\hline Safer Spaces Working Group & $\begin{array}{l}\text { Aimed at opposing } \\
\text { patriarchy and } \\
\text { addressing sexual } \\
\text { harassment, assault, } \\
\text { and oppressive } \\
\text { actions and language }\end{array}$ & $\begin{array}{l}\text { Open to } \\
\text { everyone, but } \\
\text { especially those } \\
\text { experiencing } \\
\text { marginalisation }\end{array}$ & $\begin{array}{l}\text { Facilitated the establishment of } \\
\text { community guidelines (Safer } \\
\text { Spaces 2012) } \\
\text { Created a survivors support }\end{array}$ \\
\hline
\end{tabular}




\begin{tabular}{|c|c|c|c|}
\hline & $\begin{array}{l}\text { used in the } \\
\text { encampment }\end{array}$ & & $\begin{array}{l}\text { network, providing information } \\
\text { about resources and some services } \\
\text { such as counselling and } \\
\text { accompanying victims to clinics }\end{array}$ \\
\hline Speak Easy Caucus & $\begin{array}{l}\text { Aimed to provide an } \\
\text { open space for } \\
\text { dialogue about } \\
\text { sexism, misogyny, } \\
\text { racism, etc. and } \\
\text { embolden members } \\
\text { to take up more vocal } \\
\text { positions in the GA }\end{array}$ & $\begin{array}{l}\text { Originally open } \\
\text { to anyone who } \\
\text { did not identify } \\
\text { as } 100 \text { per cent } \\
\text { male }\end{array}$ & $\begin{array}{l}\text { Helped spawn other groups such } \\
\text { as the Women's Caucus, the Safer } \\
\text { Spaces Working Group, the } \\
\text { People of Color Caucus, and the } \\
\text { Queer Caucus } \\
\text { Made a proposal, ultimately } \\
\text { rejected by the GA, that every } \\
\text { working group should do a go- } \\
\text { around and identify their gender } \\
\text { pronouns }\end{array}$ \\
\hline Strong Women Rules & $\begin{array}{l}\text { Started by a person } \\
\text { who wanted a } \\
\text { women-only tent }\end{array}$ & $\begin{array}{l}\text { (Bio-)Women } \\
\text { only }\end{array}$ & $\begin{array}{l}\text { Group's gender essentialism and } \\
\text { separatism made it very } \\
\text { contentious } \\
\text { Status unknown }\end{array}$ \\
\hline $\begin{array}{l}\text { Trans World Order Affinity } \\
\text { Group (TOAG) }\end{array}$ & $\begin{array}{l}\text { Initial goal was to } \\
\text { create a website for } \\
\text { connecting and } \\
\text { mobilising activists }\end{array}$ & $\begin{array}{l}\text { Mostly self- } \\
\text { identified women } \\
\text { and queers }\end{array}$ & $\begin{array}{l}\text { Grounded in hacker and blogger } \\
\text { culture } \\
\text { Created the } \\
\text { www.occupywallst.org website, } \\
\text { which had regular posts during } \\
\text { and after OWS that have attracted } \\
\text { a large number of site users }\end{array}$ \\
\hline Women Occupy Nations & $\begin{array}{l}\text { Felt threatened by } \\
\text { self-identified women }\end{array}$ & $\begin{array}{l}\text { (Bio-)Women } \\
\text { only }\end{array}$ & $\begin{array}{l}\text { Group's gender essentialism and } \\
\text { separatism made it very } \\
\text { contentious } \\
\text { Status unknown }\end{array}$ \\
\hline $\begin{array}{l}\text { Women Occupying Wall Street } \\
\text { (WOW) } \\
\text { https://www.facebook.com/WOW } \\
\text { SNYC }\end{array}$ & $\begin{array}{l}\text { Advocated taking an } \\
\text { intersectional } \\
\text { perspective on gender } \\
\text { within Occupy }\end{array}$ & $\begin{array}{l}\text { Self-identified } \\
\text { women, queers }\end{array}$ & $\begin{array}{l}\text { Recognised that the gender binary } \\
\text { is hurtful and patriarchal } \\
\text { Organised self-defence training } \\
\text { One of three caucuses recognised } \\
\text { by the OWS GA/Spoke council: } \\
\text { http://www.nycga.net/groups/ }\end{array}$ \\
\hline
\end{tabular}


This table points to not only the richness of practices among feminists within Occupy, but also their various understandings of feminism. Some groups, such as Feminist Direct Action and the Trans World Order Affinity Group focused on how capitalism oppresses people who do not live according to dominant gender roles, not just those who are transgendered, but anyone living outside of the heterosexual nuclear family structure. Many groups, including the Safer Spaces Working Group, the Trans World Order Affinity Group, and Women Occupying Wall Street, sought to highlight how certain conceptions of gender were contributing to systems of inequality that OWS should be trying to challenge. Amongst the different groups was a common understanding that all participants should be vigilant about gender and feminist issues in their own conduct as well as that of others, and this was one main goal towards which many feminist activists dedicated their time and energy. Nonetheless, there were frequent tensions regarding intersectional issues, gender identities, and essentialism, and many feminists at OWS were disappointed by the Feminist General Assembly (FemGA) for its lack of practical and theoretical nuance, as it often failed to build upon what had already been discussed, as well as using language and concepts that had been deemed problematic. One member of the Women Occupy Wall Street group was critical of the first two meetings of the Feminist General Assembly (FemGA):

There was a lot of gendered language and discussions around "girls", "sisterhood" and "women", which a lot of us were not comfortable with. We all went suspending our judgment and hoped for the best. But we were all disappointed. And at the second FemGA, the one that focused on LGBTQ issues, there was a question ... implying that feminist issues and queer issues are not [related]. We thought it was very problematic. (Member of Women Occupying Wall Street (WOW), interview, November 9, 2012)

Addressing these tensions was often difficult, but recognized as important by the majority of those who were aiming to construct a feminist commons. In the context of the long-time denigration of "women's work," Occupy provided an opportunity to revalue both the desire for such a space and the labor of those who helped create it.

\section{OFFLINE/ONLINE INEQUALITIES AND HIERARCHIES WITHIN OCCUPY}

One of the key accomplishments of Occupy was a reclamation and politicization - even if temporary - of public spaces. Yet these spaces were fraught from the beginning by an insufficient attention to differences in privilege and how they affected people's ability to participate, and some other recent scholarship has discussed how hierarchies of gender, sexuality, and race characterized various Occupy movements (Barker 2012; Campbell 2011; Anonymous 2012). The following sections provide a review of these conditions within OWS, then elaborate on the interplay between online and offline spaces, and conclude with a case study of attempts to create feminist online praxis.

\section{Contesting the Physical Space of Zuccotti Park}


Living in a common physical place was seen as one of the best ways to produce a shared identity, create a safer space, and help the movement evolve in more inclusive ways. Yet from its inception, Zuccotti Park was a space where the majority of people taking part in the park's activities were white (81.2 per cent) and men (61 per cent) (see Captain 2011). This demographic disproportion was widely highlighted by the mass media, not in order to provide an intersectional feminist critique, but, by and large, to discredit the movement. Nonetheless, such accounts in both the mainstream and alternative press also helped spur the involvement of women, people of colour, and queers:

I was very sceptical because the pictures I saw were a bunch of white males. [...] The reason I got involved with Occupy is that something was happening in New York City and it was my community, and I had also a responsibility to change what was happening. I went to Occupy because I did not like what was happening. (Former member of the People of Color caucus, interview, November 4, 2012)

Some feminists initially joined the movement intending to become involved in certain organizational areas such as the media working group, the facilitation team, and so on. However, in quite a few cases they went on to focus almost exclusively on intersecting inequalities, with the lack of intersectional analysis of economic issues and of Occupy's encampments themselves motivating many experienced feminist activists to devote the bulk of their efforts to that endeavour (member of WOW, interview, November 9, 2012).

The conditions of socially derived privilege were highlighted as another reason why it was easier for members of certain demographic groups to join the movement. As one occupier noted in discussing why so few women and queers were involved in working groups other than those linked to race, gender, sexual orientation, etc.:

It was easier for straight men to join any groups they wanted to join at Occupy and not join a group based on their identity, race or sexual orientation. Men did not realise that maybe the reasons why they felt so free to join any groups is that they had privileges. Many did not ask the question: Whose space am I taking and who is being silenced as a result of me taking the space. (Member of WOW, interview, November 9, 2012)

The resistance to issues of privilege, oppression, and discrimination that women and queers sought constantly to foreground was very draining and tiring, leading to complicated feelings towards Occupy. This is in accordance with the account of Anonymous (2012), a long-time feminist activist who described her initial excitement and then disenchantment with an Occupy encampment in the U.K. due to women's issues getting 'short shrift', and then her being subject to personal verbal attacks for seeking to have such issues addressed. As a feminist active at OWS noted:

what was frustrating was not only the lack of [gender and race] analysis, but also the resistance to try to build that in and the defensiveness we encountered from people to 
push for a broader analysis. (Member of the Safer Space Working Group, interview, October 24, 2012)

Despite these challenges, feminists were both instrumental in and strategic about raising consciousness about gender and other inequalities. For instance, the Safer Space Working Group facilitated the drafting of a collective community agreement, which provided guidelines on the behaviours acceptable in Occupy. The five-month process of coming up with the agreement heightened the awareness of various individuals and groups about what it means to feel secure (member of the Safer Space Working Group, interview, October 24th, 2012). Contesting the heteronormativity and patriarchy of OWS, among other things, helped shape the movement's collective imagination, and comprised an environment with more political possibility than most participants were used to. As one feminist said:

It's crazy to be in a paradigm where you have more right [than you do in the "real world"] to call out patriarchy and oppression. (Member of the FemDA, interview, November 16, 2012)

In negotiating the collective identity of OWS, feminists and queers helped the movement create common language and practices that facilitated diverse groups of people living, working, and fighting together. The key practices, some drawn from queer politics and others from earlier social movements such as the World Social Forum (see Costanza-Chock, 2012), include:

- The telling of gender pronouns. This refers to not assuming what the gender of a person is by the way they look, but rather having individuals articulate how they want to be identified. This practice was mainly used in gender-sensitive groups (WOW, PoC, FemDA, etc.)

- The use of the progressive stack, a policy in the General Assemblies (GA), aimed at elevating and giving priority to certain voices within the GA.

- The use of step up step back, a practice that aims to foster the voices of those who rarely speak, while asking those who speak a lot to step back and listen.

These practices were not panaceas. For example, some feminists have criticised progressive stack for concentrating the decision power in the hands of the facilitator and because it does not address discrimination other than those involving visibly or otherwise readily identifiable groups. And, as Jackie Smith and Bob Glidden (2012) have noted, those who had work or family responsibilities that could not be easily rescheduled were least likely to be able to participate in meetings at Occupy with no set agenda or end point. In addition, participating at Occupy was problematic for those who did not have citizenship status, particularly Latinas/Latinos, for whom arrest could lead to deportation (Puente 2012). Nevertheless, it is important to recognize the extent to which feminist practices did address the privileges of gender, sexuality, race, and class in the OWS encampment. In the next section, we introduce the challenges for extending feminist analyses and practices to OWS's online spaces. 


\section{Contesting the Cyberspace of OWS}

Understanding how power plays out online - even within activist circles - is essential for productive digital activism, including crafting feminist spaces. While some offline power relationships also manifest in the virtual world, others emerge from the specificities of the new technologies. Saskia Sassen (2002) argues that there are no purely digital or exclusively virtual electronic spaces; rather, online spaces are always embedded in the material. Occupy Wall Street has been one prominent example of this, although participants varied in the extent to which they were invested in shaping the character of the movement's online spaces.

When talking about creating an inclusive culture in both the virtual and physical realms of the movement, one occupier commented that:

I guess it comes down to creating a movement in which certain practices are just not ok [...] within the movement, but also outside of it. [...] everyone should be saying 'What are you doing? That's not ok.' And creating this culture within ourselves. (Member of the PoC Caucus, interview, October 24, 2012)

However, there was no consensus about how to achieve this or even about the importance of cyberspace to Occupy's goals. Some participants articulated a somewhat technological deterministic viewpoint that it was largely thanks to Twitter, Facebook, Tumblr and livestreaming that OWS grew so quickly (member of the media team, interview, December 9, 2012). Others noted that while social media helps a movement become better known, it cannot and should not substitute for face-to-face interaction (member of the New Yorkers Against Budget Cuts, interview, October 15, 2012).

Thus, one challenge for creating safer spaces online was that many feminist and queer participants accorded greater importance to the decisions and debates happening in the encampment than to online activities associated with Occupy. In addition, even though there were clearly challenges in addressing offline inequalities at OWS, several interviewees felt that in face-to-face interactions, a group could more easily negotiate disagreement and lower escalation, while promoting feminist, queer and trans practices online was more difficult, particularly with people who had less experience with online decision-making (Kavada 2005). Those who raised issues of racism, transphobia and sexism within OWS often faced hostility, and experiences or fears of online backlash may have deterred some feminist and queer occupiers from more cyberspace participation; as one occupier noted about her experience, 'It was much easier for people to be mean and discriminatory online' (member of the media team, interview, November 5, 2012).

Amidst such a complex context, Occupy Wall Street provided an excellent venue to observe how activists approached the goals of raising awareness about intersectional practices online, developing strategies to lessen online bashing, and linking these actions to a radical political project. In the next section, we describe how one group within OWS, TOAG, enacted its own online feminist, queer and trans praxis in ways that had a significant impact on the movement. 


\section{Occupy's Feminist Online Spaces: The Trans World Order Affinity Group as a Case Study}

Individuals who did not feel comfortable participating in activities held at Zuccotti Park or those who did not have the necessary time or the status (for example, undocumented immigrants) could experience agency through virtual participation. Here, the distinction between individual agency and collective agency is important. While individual agency draws on the politics of personalisation and individuation, collective agency is anchored in more collaborative processes that often involve long periods of negotiation (Micheletti 2003; Bennett 2012). In the virtual sphere, the distinction between individual and group viewpoints is often erased (Fenton and Barassi 2011), since the voice of an individual can be as powerful as the voice of a group whose viewpoint emerged only after lengthy discussion. This raises particular issues for activist groups seeking to express a collaboratively produced radical agenda.

The virtual collective agency grounded in radical cyberfeminism is well illustrated by TOAG, whose membership draws from those sensitive to non-normative gender expression, mostly comprising self-identified women (half of them transwomen) and queers, among whom are journalists, hackers, software developers and other social media savvy individuals. With many of its members having struggled against homelessness, discrimination, and transphobia, coupled with the difficulty of operating a communication hub outdoors, TOAG decided to act outside of Zuccotti Park while remaining an important voice countering the gender oppression that many encountered in their daily lives. The fact that, for many months prior to eviction, many TOAG members lived in the same squatted apartment as they worked on the OccupyWallSt.org website and related social media projects served to strengthen their affect and collective commitment.

In July 2011, Justine Tunney, who would become a founding member of TOAG, registered the OccupyWallSt.org site (Schwartz 2011), which TOAG soon developed into a communication and tech hub according to the free/libre/open source software (FLO) model. As was wellchronicled in the mainstream media, Adbusters, the Canadian countercultural magazine, had bought the OccupyWallStreet.org domain name in June 2011 before launching its call to 'Occupy Wall Street'. TOAG's actions were thus a calculated risk, carefully crafted and planned in advance to construct their own distinct feminist Occupy community online. Anticipating that Adbuster would not provide significant help with actually organising the occupation of Wall Street, TOAG's goal was to function as a mobilising tool to connect activists, rather than leaving it only to Adbuster. As one TOAG member explained, the group thought that if 'Adbuster says do it, probably a few dozen people will show up, but if we give them the tools to meet up somewhere then more might show up' (member of the Trans World Order Affinity Group, interview, November 21, 2012). Thus, while TOAG's planning was perhaps not as visible as actions at the physical encampment, it was nonetheless akin to them. OccupyWallSt.org remains an active site, in contrast to Adbuster's OccupyWallSt.org site, which now redirects to a page off Adbuster's main domain that lists various other Occupy sites, including TOAG's. Despite this, there has been little recognition of TOAG's central involvement (but see Schwartz 2011). 
TOAG sought to create safe spaces online and offline, following a safer space model ${ }^{2}$ where participants shared common values that they committed to abide by. One element of safety derived from putting forth a collective voice, so TOAG never attached individual names to articles. ${ }^{3}$ Prioritizing group goals was sometimes in tension with dominant practices around personal recognition, as one member commented:

We never used our names, we never wanted credit. For us it was about the movement, it was not about us. Unfortunately some people use that to get credit and the mainstream media wants to attribute credit to individuals. (Member of the Trans World Order Affinity Group, interview, November 21, 2012)

Still, not attributing articles to particular individuals was effective in exploiting the possibilities of the web, reducing the possibilities of members suffering personal attacks online and distributing the anxiety that any one person might feel if they were publishing in their name alone. As a TOAG member explained:

Essentially we are bloggers. So that's what protected us. None of us participated in direct actions; we might tweet about it, write about it, we might announce it on our website, but we didn't go to these actions. And that has something to do with our roles as journalists, but also because we are transwomen and the repression that we potentially face within the criminal justice system. We don't feel we are 'arrestable' for our own mental health and the situation we would encounter there [in prison]. (Member of the Trans World Order Affinity Group, interview, November 21, 2012)

While the TOAG website was mostly text-based and not individually personalized, the posts often reflected its members' feminist, trans and queer commitments. As a case in point, on November 8, 2011, the TOAG collective called for all of OWS's General Assemblies to adopt anti-harassment and anti-assault "policies" as core principles of solidarity. This was an attempt to create safer spaces for women and LGBTQ participants (see OccupyWallSt.org 2011a) and, along with the Declaration of the Occupation of New York City and the Principles of Solidarity, was recognized by TOAG as one of the pillars of the movement (see OccupyWallSt.org n.d.). Moreover, on November 18, TOAG published a statement that called for supporting the selfdetermination of all people oppressed by coercive, non-consensual gender assignments (see OccupyWallSt.org 2011b). The latter made explicit TOAG's politics regarding trans issues within the Occupy movement and is well articulated by one of the group's members:

I think we succeeded in broadening the discourse to not only talking about the rich, but also talking about social justice issues such as trans-rights, and organising around issues

\footnotetext{
${ }^{2}$ TOAG's online project was similar in many ways to that of the Safer Space working group, whose efforts TOAG supported and highlighted online.

${ }^{3}$ They also made it clear that they were by no means the only ones speaking for Occupy, with their Twitter account declaring "We are only one Twitter voice of the movement."
} 
of police brutality, community issues, people of colour issues, poor people issues, rather than what a lot of people wanted to do, to purely focus on campaigns. (Member of the Trans World Order Affinity Group, interview, November 21, 2012)

The trans-embodiment of the TOAG was thus embraced discursively online as well as offline in the safer space they created. As one occupier said:

Transpeople flourished at Occupy. But it's not visible. Many LGBTQs found that [online] space safer than trying to have shout outs in the GA. People who did not feel comfortable presenting themselves in public could thrive in the online realm and contribute in constructive ways. (Member of the media team, interview, November 5, 2012)

The genuine feelings of online safety expressed notwithstanding, it is important not to take statements like these as indicative of the Internet as a libertarian utopia of disembodiment or as inherently feminist, such as some earlier scholars (for example, Plant 1997) suggested. In addition, while the identities of TOAG members are somewhat hidden from the public sphere, some members recounted how their apartment was monitored at various times by the police and the harassment they incurred because TOAG was so central to Occupy's communication efforts. Also, even as the group was able to create safer spaces online where discrimination, trolling, and bashing were comparatively reduced, some Occupy activists did not regard TOAG's online work as having the same validity as occupying Zuccotti Park, failing to recognize the particular issues of physical safety for transwomen. One TOAG member recalled:

Militant folks [were] saying why are you not willing to put your body on the line? White cis-male guys would say, 'It's not that bad to be arrested.' Having no idea what it is like to be in jail for a trans-woman. And as if the kind of work we were doing was less valid. (Member of the Trans World Order Affinity Group, interview, November 21, 2012)

Still, the sheer numbers of comments on each of TOAG's blog entries, often ranging from 100 to 400 , speak volumes to the popularity of their well-crafted virtual endeavours; their Twitter account@OccupyWallSt had nearly 189,000 followers and their Facebook page more than 420,000 likes as of September 2013. Thus, in various ways, TOAG successfully harnessed the Internet to foreground issues dear to the Occupy movement and, in turn, to help shape the Occupy identity, while at the same time also advancing a trans, queer and feminist agenda. 
However, even for TOAG, the virtual space partly mirrored the gendered division of labour in the encampment. With writing, editing, tweeting ${ }^{4}$ and facebooking requiring relatively low levels of technological proficiency, one member observed:

[Self-identified] women and queers did most of the writing and editing. They took care of social media, the Twitter, Facebook and Reddit accounts. The behind the scenes stuff. It was mostly white men that did and held the livestream cameras and who did the narration. I got sick of hearing the guys. [...] It was also the men who were presented as being the leaders of the movement in the media. (Member of the Trans World Order Affinity Group, interview, November 21, 2012)

Despite these issues, TOAG has benefited from the loose networking nature of Occupy and its meta-political frame of contestation ${ }^{5}$ to influence not only the discourse in New York City, but also elsewhere in the USA and beyond. TOAG members view the group's endeavour as larger than OWS, committed to sharing political strategies and energies with popular uprisings around the world, such as Spain's M15 (May 15) movement (a.k.a. Indignados) (member of the Trans World Order Affinity Group, interview, November 21, 2012). As activists in other movements have confronted inadequate analyses of multiple intersecting inequalities, TOAG is one influential project that has helped expand this discourse. TOAG continues to touch base with domestic and global movements, recently expressing solidarity with the World Social Forum in Tunisia (OccupyWallSt.org 2013b) as well as protests against police violence in the U.S. (OccupyWallSt.org 2013a). Thus, although the online realm has been rife with harassment and discrimination towards those who foreground explicitly feminist principles, the TOAG case study points to the demonstrable online successes of trans and queer people undertaking a feminist media project in a prominent activist setting.

\section{Conclusion}

Occupy was a major mobilization that began as a challenge to capitalism and class inequalities, and then developed into spaces that to varying extents enabled additional critiques about other hierarchies and oppressions. It has therefore provided opportunities to (re)create connections between groups that had largely been fighting in separate corners for many years. The loose distributed networks that characterised Occupy both online, but especially offline, gave visibility

\footnotetext{
${ }^{4}$ Despite the fact that the medium is dominated by women (64 per cent of women are users), tweeting about Occupy was apparently dominated by men, with only 30 per cent of tweets made by women (see Frazen 2011).

${ }^{5}$ In the past few years, various social movements have shifted the terms of opposition from thematic focuses (for example, 'feminist' or 'environmental' movements) to a larger frame of contestation termed 'meta-political.' This occurred during the Occupy movement as well, as many activists moved away from single-issue organising to making explicit links between different forms of oppressions (member of the People of Color caucus, interview, October 24, 2012). Thus, they framed their discourses to highlight how capitalism, austerity measures, patriarchy, sexism, and racism, among others, are interdependent and mutually reinforcing.
} 
to a variety of struggles and also helped push the movement away from a single-issue approach, demonstrating the extent to which the unity in diversity frame can function successfully in social movements. Nonetheless, it was also challenging to create spaces of productive dialogue, where those who were marginalized could come forward while those with more power would acknowledge the inequalities and exclusions informing their interactions and decision-making. Understanding the dynamics of privilege led many to react very defensively, and feminists at Occupy were often accused of being divisive or criticized at a more personal level.

This was particularly apparent during endeavours to create feminist online praxis. Feminists who denounced patriarchal behaviours occurring offline or online risked belittlement, ostracism, or harsh criticism and verbal bashing. Nonetheless, the TOAG case study is an example of an influential online feminist space that contested norms of gender identity and expression, and its successes are highlights for future feminist efforts online. TOAG's online and offline spaces foregrounded collective voices, provided glocal perspectives and facilitated transnational solidarity with other groups, harnessing much of the technical and discursive potential of cyberspace while minimising personal attacks. Their achievements deserve much more attention from scholars not just of Occupy, but of online activism, feminist practice, and digital technologies more broadly.

There were effective activist efforts by various other feminist groups of Occupy that we did not discuss, and additional possibilities for feminist online praxis that we could not fully explore in this paper. One avenue involves working with digital code, drawing from technofeminist cultures in order to design architecture that would be feminist at its core and offer, for instance, alternatives to the commercialized services of Facebook, Twitter and the like (for example, Wajcman 2004). Online gaming is another domain where feminist critique and practices have emerged in relation to both play and design (see Everett 2009; Fullerton, Morie and Pearce 2007; Huntemann 2010). Collectively, these point to how a range of individual and collaborative practices are needed to challenge dominant norms of gender, sexuality, class, race, and ethnicity and to promote safer, more equitable spaces of interaction online.

Finally, a larger issue about the relationship between activism in physical and virtual contexts has recently come to the fore in popular and academic discussions, and evaluating the efficacy of online activism will no doubt persist as a key question. What our paper has demonstrated is the importance of not treating all forms of 'digital activism' as equal, given the scope and amount of work that a group like TOAG has contributed, as well as the effectiveness of movements that make use of both offline and online practices. Continued investigations of feminist online activism should present a rich set of empirical and theoretical projects for those of us invested in the role of new media in more participatory forms of protest and engagement.

\section{References}


Ahmed, S. (2010). The Promise of Happiness. Durham, NC: Duke University Press

Ahmed, S. (2004). The Cultural Politics of Emotion. London: Routledge

Anonymous (2012) 'Occupy - The End of the Affair', Social Movement Studies, 11(3-4), 44145

Alcoff, L. M. (2012) 'Feminism: Then and Now' Journal of Speculative Philosophy, 26(2), 26878

Arruzza, C. (2012) 'The Gender of Occupy Wall Street', International View Point [online], March 12. Accessed April 15, 2013. Accessible at

http://www.internationalviewpoint.org/spip.php?article2610

Barker, A. J. (2012) 'Already Occupied: Indigenous Peoples, Settler Colonialism and the Occupy Movements in North America', Social Movement Studies, 11(3-4), 327-34

Behar, R. and Gordon, D. (eds) (1995), Women Writing Culture, Berkeley: University of California Press

Bennett, W. L. (2012) 'The Personalization of Politics: Political Identity, Social Media, and Changing Patterns of Participation', The Annals of the American Academy of Political and Social Science, 644(1), 20-39

Bennett, W. L. and Segerberg, A. (2011) 'Digital Media and the Personalization of Collective Action', Information, Communication \& Society, 14(6), 770-99

Boler, M. (2012) 'Occupy Women: Will Feminism's Fourth Wave be a Swell or a Ripple?', Truth Out, [online], May 16. Accessed April 15, 2013. Accessible at http://truthout.org/news/item/9188-occupy-women-will-fourth-wave-feminism-be-a-wave-or-a-ripple

Brenner, N. and Theodore, N. (2002) 'Cities and the Geographies of "Actually Existing Neoliberalism"', in N. Brenner and N. Theodore (eds), Spaces of Neoliberalism: Urban Restructuring in North America and Western Europe, Oxford: Blackwell, pp. 2-32

Campbell, E. R. A. (2011) 'A Critique of the Occupy Movement from a Black Occupier', The Black Scholar, 41(4), 42-51 
Campbell, J. E. (2004), Getting it on Online: Cyberspace, Gay Male Sexuality, and Embodied Identity, New York: Haworth Press

Captain, S. (2011) 'Infographic: Who is Occupy Wall Street?' Fast Company, [online], November 1. Accessed April 15, 2013. Accessible at http:/www.fastcompany.com/1792056/infographic-who-occupy-wall-street

Carpentier, N. (2007), 'Theoretical Frameworks for Participatory Media', in N. Carpentier, P. Pruulmann-Vengerfeldt, K. Nordenstreng, M. Hartmann, P. Vihalemm, B. Cammaerts and H. Nieminen (eds), Media Technologies and Democracy in an Enlarged Europe, Tartu, Estonia: Tartu University Press, pp. 105-22

Castells, M. (2012), Networks of Outrage and Hope: Social Movements in the Internet Age, Cambridge: Polity Press

Castells, M. (2008), 'The New Public Sphere: Global Civil Society, Communication Networks, and Global Governance', Annals of the American Academy of Political and Social Science, 616(1), 78-93

Clifford, J. (1986), 'Introduction: Partial Truths', in J. Clifford and G. Marcus (eds), Writing Culture: The Poetics and Politics of Ethnography, Berkeley: University of California Press, pp. $1-26$

Cockburn, C. (1985), Machinery of Dominance: Women, Men and Technical Know-how, London: Pluto

Conroy, A. (2012) 'Slammed by Government Cuts and Sidelined by the Occupy Movements, Women Face an Uphill Battle to Challenge Patriarchy in 2012', British Politics and Policy at LSE, [online], January 5. Accessed April 15, 2013. Accessible at http://blogs.lse.ac.uk/politicsandpolicy/archives/19273

Costanza-Chock, S. (2012) 'Mic Check! Media Cultures and the Occupy Movement, Social Movement Studies, 11(3-4), 375-85

Daniels, J. (2009) Cyber Racism: White Supremacy Online and the New Attack on Civil Rights, Lanham, MD: Rowman \& Littlefield 
Davis, R. and Owen, D. (1998), New Media and American Politics, Oxford: Oxford University Press

della Porta, D. (2005) 'Between the European Social Forum and the Local Social Fora', in D. della Porta \& S. Tarrow (eds), Transnational Protest and Global Activism, Lanham, MD: Rowman \& Littlefield Publishers, pp. 175-202

Eubanks, V. (2011) Digital Dead End: Fighting for Social Justice in the Information Age, Cambridge, MA: MIT Press

Everett, A. (2009) 'Serious Play: Playing with Race in Contemporary Gaming Culture', in A. Everett, Digital Diaspora: A Race for Cyberspace, Albany, NY: State University of New York Press, pp. 109-46

Fenton, N. and Barassi V. (2011) 'Alternative Media and Social Networking Sites: The Politics of Individuation and Political Participation', The Communication Review, 14(3), 179-96

Frazen, C. (2011) 'Occupy Wall Street Twitter Mentions Reveal Gender Disparity', TPM Livewire, [online] October 20. Accessed April 15, 2013. Accessible at http://idealab.talkingpointsmemo.com/2011/10/occupy-wall-street-twitter-mentions-revealgender-disparity.php

Freeman, J. (1972) 'The Tyranny of Structurelessness', The Second Wave, 2(1), 20

Fullerton, T., Morie, J. F. and Pearce, C. (2007) 'A Game of One's Own: Towards a New Gendered Poetics of Digital Space', conference paper, Digital Arts and Culture Conference, Perth, Australia

Gajjala, R. (2002) 'An Interrupted Postcolonial/Feminist Cyberethnography: Complicity and Resistance in the "Cyberfield", Feminist Media Studies, 2(2), 177-93

Gladwell, M. (2010) 'Small Change: Why the Revolution will not be Tweeted', The New Yorker. [online], October 4. Accessed April 15, 2013. Accessible at http://www.newyorker.com/reporting/2010/10/04/101004fa fact gladwell?currentPage=all

Halpin, Z. T. (1989) 'Scientific Objectivity and the Concept of "the Other"', Women's Studies International Forum, 12(3), 285-94 
Hardt, M. \& Negri, A. (2009) Commonwealth, Boston, MA: Harvard University Press.

Huntemann, N. B. (2010) 'Irreconcilable Differences: Gender and Labor in the Video Game Workplace, Flow, [online], 11(6). Accessed April 15, 2013. Accessible at http://flowtv.org/2010/01/irreconcilable-differences-gender-and-labor-in-the-video-gameworkplace-nina-b-huntemann-suffolk-university/

Jenkins, H. (2006) Convergence Culture: Where Old and New Media Collide, New York: New York University Press

Juris, J., Ronayne, M., Shokooh-Valle, F., and Wengronowitz, R. (2012) 'Negotiating Power and Difference within the 99\%', Social Movement Studies, 11(3-4), 434-40

Kavada, A. (2010) 'Between Individuality and Collectiveness: Email Lists and Face-to-face Contact in the Global Justice Movement', International Journal of E-Politics, 1(1), 41-56

Kavada, A. (2005) 'Civil Society Organizations and the Internet: The Case Studies of Oxfam, Amnesty International and the World Development Movement', in W. de Jong, M. Shaw and N. Stammers (eds), Global Activism, Global Media, London: Pluto Press and Ann Arbor: University of Michigan Press, pp. 208-22

Kendall, L. (2002) Hanging out at the Virtual Pub: Masculinities and Relationships Online, Berkeley: University of California Press

Larsen, A. (2004) 'Affective Technologies - Emotions and Mobile Phones', Receiver: Connecting to the Future, [online], 11, 1-8. Accessed April 15, 2013. Accessible at http://www.academia.edu/472410/Affective Technologies. Emotions and Mobile Phones

Marcus, G. (1998) 'On Ideologies of Reflexivity in Contemporary Efforts to Remake the Human Sciences', in G. Marcus, Ethnography Through Thick and Thin, Princeton, NJ: Princeton University Press, pp. 181-202

McMillan, G. (2011) 'Why Aren't Women Tweeting about Occupy Wall Street?', Time Tech Section, [online], October 21. Accessed April 15, 2013. Accessible at http://techland.time.com/2011/10/21/why-arent-women-tweeting-about-occupy-wall-street/ 
Micheletti, M. (2003) Political Virtue and Shopping: Individuals, Consumerism and Collective Action, New York: Palgrave-Macmillan

Nakamura, L. (2007) Digitizing Race: Visual Cultures of the Internet, Minneapolis: University of Minnesota

Nakamura, L. (2002) Cybertypes: Race, Ethnicity, and Identity on the Internet, London: Routledge

OccupyWallSt.org (n.d.), 'What Do We Stand For?', OccupyWallSt.org, [online]. Accessed April 15, 2013. Accessible at http://www.occupywallst.org/about/

OccupyWallSt.org (2011a) 'Everyone has the right to occupy space, safely', OccupyWallSt.org, [online], November 8. Accessed April 15, 2013. Accessed at http://occupywallst.org/article/everyone-has-right-occupy-space-safely/

OccupyWallSt.org (2011b) 'OWS Must Resist Cis-supremacy and Trans-misogyny', OccupyWallSt.org, [online], November 18, [authorship attributed to 'A bunch of trans women']. Accessed April 15, 2013. Accessible at www.occupywallst.org/media/pdf/trans-statement.pdf

OccupyWallSt.org (2013a) ‘All out for Kimani!', OccupyWallSt.org, [online], March 23. Accessed April 15, 2013. Accessed at http://occupywallst.org/forum/all-out-kimani/

OccupyWallSt.org, (2013b) 'Declaration of the Social Movements Assembly', OccupyWallSt.org, [online], April 3. Accessed April 15, 2013. Accessible at http://occupywallst.org/article/declaration-social-movements-assembly/

Patai, D. (1991) 'U.S. Academics and Third World Women: Is Ethical Research Possible?', in S. B. Gluck and D. Patai (eds), Women's Words: The Feminist Practice of Oral History, New York: Routledge, pp. 137-53

Peterson, M. (2006) 'Patrolling the Plaza: Privatized Public Space and the Neoliberal State in Downtown Los Angeles', Urban Anthropology and Studies of Cultural Systems and World Economic Development, 35(4), 355-386

Plant, S. (1997) Zeroes and Ones: Digital Women and the New Technoculture, New York: Doubleday 
Polson, E. (2011) 'Belonging to the Network Society: Social Media and the Production of a New Global Middle Class', Communication, Culture and Critique, 4(1), 144-63

Probyn, E. (1993) 'Moving Selves and Stationary Others: Ethnography’s Ontological Dilemma', in E. Probyn, Sexing the Self: Gendered Positions in Cultural Studies, New York: Routledge, pp. $58-81$

Puente, N. and Jiménez, A. G. (2009) 'New Technologies and New Spaces for Relation: Spanish Feminist Praxis Online, European Journal of Women's Studies, 16(3), 249-53

Puente, N. (2011), 'Feminist Cyberactivism: Violence Against Women, Internet Politics, and Spanish Feminist Praxis Online', Continuum: Journal of Media and Cultural Studies, 25(3), $333-46$

Puente, T. (2012) 'Will Latino Groups Choose to Occupy?', In These Times, 36(1), 12-13

Queer/LGBTQIA2Z Caucus (2011) 'Queering OWS: Radical Language Road Guide', Queer $O W S$, [online]. Accessed April 15, 2013. Accessible at

http://queerows.files.wordpress.com/2011/12/queerlanguageguide.pdf

Safer Spaces (2012) 'Occupy Wall Street Community Agreement, NYC General Assembly, [online], January 18. Accessed April 15, 2013. Accessible at http://www.nycga.net/groupdocuments/occupy-wall-street-community-agreement-jan-18-2012-proposed-by-safer-spaces/

Sassen, S. (2002) 'Towards a Sociology of Information Technology, Current Sociology, 50(3), $365-88$

Schwartz, M. (2011) 'Pre-Occupied: The Origins and Future of Occupy Wall Street', The New Yorker, [online], November 28. Accessed April 15, 2013. Accessible at http://www.newyorker.com/reporting/2011/11/28/111128fa_fact_schwartz?currentPage=all

Smith, D. (2004) 'Women's Perspective as a Radical Critique of Sociology', in S. N. HesseBiber and M. L. Yaiser (eds), Feminist Perspectives on Social Research, New York: Oxford University Press, pp. 27-38 
Smith, J. \& Glidden, B. (2012) 'Occupy Pittsburgh and the Challenges of Participatory Democracy’ Social Movement Studies, 11(3-4), 288-94

Stiegler, B. (2008) Acting Out. Stanford, CA: Stanford University Press.

Strange, S. (1997) Casino Capitalism, Manchester: Manchester University Press

Talcott, M. \& Collins, D. (2012) 'Building a Complex and Emancipatory Unity: Documenting Decolonial Feminist Interventions within the Occupy Movement', [photo essay], Feminist Studies, 38(2) [n.p.]

Terranova, T. (2000) 'Free Labour: Producing Culture for the Digital Economy', Social Text, $18(2), 33-58$

Terranova, T. (2004) Network Culture: Politics for the Information Age, London: Pluto Press

Tilly, C. (2004) Social Movements, 1768-2004, Boulder, CO: Paradigm Publishers

Turner, G. (2009) Ordinary People and the Media: The Demotic Turn, London: Sage

Wajcman, J. (2004) Technofeminism, Cambridge, UK: Polity

White, M. (2010) 'Clicktivism is Ruining Leftist Activism', The Guardian, [online], August 12. Accessed April 15, 2013. Accessible at http://www.guardian.co.uk/commentisfree/2010/aug/12/clicktivism-ruining-leftist-activism 